\title{
o2. Türkçe Dersi Öğretim Programı'ndaki kazanımların Webb’in Bilgi Derinliği Seviyelerine göre analizi
}

\author{
Ahmet KARABULUT' \\ Muhammed TUNAGÜR²
}

\begin{abstract}
APA: Karabulut, A.; Tunagür, M. (2021). Türkçe Dersi Öğretim Programı'ndaki kazanımların Webb'in Bilgi Derinliği Seviyelerine göre analizi. RumeliDE Dil ve Edebiyat Araştırmaları Dergisi, (23), 15-29. DOI: $10.29000 /$ rumelide.948285.
\end{abstract}

\section{$\ddot{\mathbf{O z}}$}

Bu araştırmada, 2019 Türkçe Dersi Öğretim Programı’ndaki kazanımların Webb’in bilgi derinliği seviyeleri açısından değerlendirilmesi amaçlanmıştır. Çalışma nitel araştırma yöntemine göre gerçekleştirilmiş ve bu kapsamda doküman incelemesi yöntemi kullanılmıştır. Araştırmanın veri toplama aracını, (çalışma materyali) 2019 yılında yayımlanan Türkçe Dersi Öğretim Programı oluşturmaktadır. Elde edilen veriler, betimsel analiz yolu ile analiz edilmiştir. Araştırma sürecinde Webb’in bilgi derinliği ile ilgili literatür taraması yapılarak tematik çerçeve oluşturulmuş ve 2019 Türkçe Dersi Öğretim Programı'nda yer alan 5, 6, 7 ve 8. sınıfa ait kazanımlar liste halinde çıkarılmıştır. Her bir kazanım Webb’in Bilgi Derinliği Seviyelerine uygun oldukları bir veya birden fazla seviye ile kodlanmıştır. Webb’in Bilgi Derinliği Seviyelerinde sınıf bazında en fazla bilgi seviyesinin seviye 2'de toplandığı, bu bilgi seviyesini seviye 3 ve seviye 1'in takip ettiği görülmektedir. En üst basamak olan seviye 4'ün ise kazanımlarda çok az yer kapladığı, 5. ve 6. sinıf ile 7. ve 8. sınıfın bilgi derinliği seviyelere göre yüzdelik ortalamalarının birbirlerine yakın oldukları görülmektedir. Türkçe Dersi Öğretim Programında yer alan ortaokul seviyesi kazanımlarının yarısına yakınının 2. seviyede, \%25'e yakınının 3. seviyede, kazanımların \%20' ye yakınının 3 . Seviyede ve son olarak da \%5 civarlarında 4. Seviyede dağılım gösterdiğine ulaşılmıştır. Elde edilen bulgular, kazanımların genellikle 2. Seviye yani yetenekler ve kavramlar kısmında yığılma gösterdiğini, stratejik düşünmeye yönelik kazanımların \% 20, geniş düşünmeye dönük kazanımların ise sadece \% 5 seviyesinde dağllım göstermesi, programın üst düzey düşünme becerilerine çok fazla yer ayırmadığını göstermektedir.

Anahtar kelimeler: Türkçe dersi, öğretim progamı, Webb’in bilgi derinliğ, kazanım

\section{The knowledge of Webb's knowledge of the achievements in the Turkish Language Teaching Program analysis by depth levels}

\begin{abstract}
In this research, it is aimed to evaluate the achievements in the 2019 Turkish Language Curriculum in terms of Webb's level of knowledge. The study was carried out according to the qualitative research method. In this context, document review method was used. The data collection tool of the research consists of the Turkish Lesson Curriculum published in 2019. The obtained data were analyzed by descriptive analysis. During the research process, the thematic framework was created
\end{abstract}

Arş. Gör. Dr., Ağrı İbrahim Çeçen Üniversitesi, Eğitim Fakültesi, Türkçe ve Sosyal Bilgiler Eğitimi Bölümü, Türkçe Eğitimi ABD (Ağrı, Türkiye), karabulut.ahmet25@gmail.com, oooo-oo02-2222-4078 [Araştırma makalesi, Makale kaylt tarihi: 13.03.2021-kabul tarihi: 20.06.2021; DOI: 10.29000/rumelide.948285]

2 Arş. Gör. Dr., Ağrı İbrahim Çeçen Üniversitesi, Eğitim Fakültesi, Türkçe ve Sosyal Bilgiler Eğitimi Bölümü, Türkçe Eğitimi ABD (Ağrı, Türkiye), mutanagur@hotmail.com, oooo-0002-6427-6431

Adres | Address

RumeliDE Dil ve Edebiyat Araşttrmaları Dergisi $\quad$ RumeliDE Journal of Language and Literature Studies Osmanağa Mahallesi, Mürver Çiçeği Sokak, No:14/8 Osmanağa Mahallesi, Mürver Çiçeği Sokak, No:14/8

Kadıköy - İSTANBUL / TÜRKIYE 34714 Kadıköy - ISTANBUL / TURKEY 34714 e-posta: editor@rumelide.com

e-mail: editor@rumelide.com,

tel: +90 505 7958124, +90 2167730616 phone: +90 505 7958124, +90 2167730616 
The knowledge of Webb's knowledge of the achievements in the Turkish Language Teaching Program analysis by depth levels / A. Karabulut; M. Tunagür (pp. 15-29)

\begin{abstract}
by scanning the literature on the depth of knowledge of Webb and the acquisitions of the $5^{\text {th }}$ 6th, 7th and 8th grade in the 2019 Turkish Language Curriculum were listed. Each acquisition is coded with one or more levels that are suitable for Webb's knowledge depth levels. It is seen that in Webb's depth of knowledge levels, the highest level of knowledge on class basis is gathered at level 2 , followed by level 3 and level 1 . It is seen that the highest level, level 4, occupies very little space in achievements, and the percentage averages of the 5 th and 6th grade and 7th and 8th grade are close to each other according to the depth of knowledge levels. It was found that almost half of the middle school level gains in the Turkish Lesson Program were at the 2nd level, 25\% at the 3rd level, 20\% of the gains at the 3 rd level, and finally around $5 \%$ at the 4 th level. The findings show that the achievements are generally accumulated in the 2nd level, namely the skills and concepts, the distribution of the gains for strategic thinking at the level of $20 \%$ and the acquisitions for broad thinking at the level of only $5 \%$ shows that the program does not devote much to high-level thinking skills.
\end{abstract}

Keywords: Turkish lesson, teaching program, Webb's depth of knowledge, outcome

\title{
Giriş
}

Teknolojinin gelişmesi; bilginin çoğalmasına, bilgiye kolayca ulaşılmasına ve dolayısıyla bilgi kirliliğine sebep olmaktadır. Bundandır ki günümüzde, bireyin hazır bilgiye ulaşmaktan ziyade bilgiyi üretmesi amaçlanmaktadır. Teknoloji çağında gerçekleştirilmesi hedeflenen birey modeli, bilgiyi olduğu gibi kabul eden değil bilginin oluşturulma ve zihinde yapılandırma sürecine aktif olarak katkı sunandır (Yıldırım ve Şimşek, 2008:224).

Bilgiyi edinme ve zihinde yapılandırma süreci ise eğitimle gerçekleşebilir. Eğitim ise; bireyin kendi yaşantısı bağlamında, istendik davranışları ve becerileri elde etmesi olarak tanımlanan süreçtir. Bu uzun süreçte öğrenen ve öğretenlere rehber olan ise öğretim programlarıdır. Öğretim programı; bireye, okul içinde ve okul dışında planlanmış etkinlikler yoluyla sağlanan öğrenme yaşantıları örüntüsüdür (Demirel, 2012: 6). Dünyada değişen sistemler ve yeni ihtiyaçlar dâhilinde eğitim programları da ülkelerin gereksinimlerine ve bu gereksinimleri belirlemek üzere yapılan analizlere göre yenilenmektedir. Öğretim programlarının içeriğinin bulunulan dönemin gereklerini karşılayamaması ya da istenen sonuçların alınamaması, öğretim programlarının yenilenmesini gerekli kılabilir. Nitekim ülkemizde de ortaokul seviyesindeki ana dili öğretim programı, farklı dönemlerde yenilenmiş ve değiştirilmiştir. Çünkü toplumsal canlılık, eğitim programlarının da değişken ve esnek olmasını gerektirmektedir.

21. yüzyılın ortasından itibaren eğitimde yaşanan değişimler ve gereksinimler, yeni bakış açılarına dayanan eğitim sistemlerini zorunlu kılmış ve kökleri Kant'a uzanan, 1960'lı yıllarda Bruner tarafından geliştirilen yapılandırmacı anlayışı ortaya çıkarmıştır (Özerbaş, 2007:611). Ülkemizde de bu minvalde 2004 yılında yayımlanıp 2005 yılında uygulanmaya başlayan yapılandırmacılık esaslı Türkçe Öğretim Programı uygulanmaktadır. Yapılandırmacılıkta esas, öğrencinin merkeze alınarak öğretmenin rehber görevini üstlenmesi ve bireyin yaparak, yaşayarak, araştırarak öğrenmesini sağlamaktır.

Dil eğitimi, iletişim ve akademik başarı bağlamında ilkokul 1. sınıftan itibaren büyük bir önem taşımaktadır. Öğrencilerin ilköğretim çăglarında kazanacakları dil becerileri, onların hem eğitim hem de sosyal hayatlarını başarılı ve sorunsuz bir şekilde devam ettirmelerini sağlayacaktır (Güzel \&

\footnotetext{
Adres $\mid$ Address

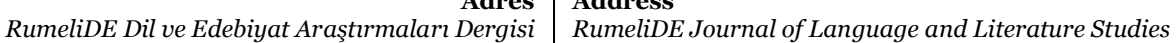
Osmanağa Mahallesi, Mürver Çiçeği Sokak, No:14/8 Osmanağa Mahallesi, Mürver Çiçeği Sokak, No:14/8 Kadıköy - İSTANBUL / TÜRKIYE 34714 Kadıköy - ISTANBUL / TURKEY 34714 e-posta: editor@rumelide.com e-mail: editor@rumelide.com tel: +90 505 7958124, +90 2167730616 phone: +90 505 7958124, +90 2167730616
} 
Karadağ, 2013: 46). Bu noktada bu eğitimin ne zaman, nasıl ve ne kadar verilmesi gerektiği sorusu ortaya çlkmaktadır. Bu soruların yanıtları ise, öğretim programlarında yer almaktadır.

Türk Millî Eğitiminin Genel Amaçları ile Türk Millî Eğitiminin Temel İlkeleri temele alınarak hazırlanan 2019 Türkçe Öğretim Programı; okul öncesi, ilkokul, ortaokul ve lisede farklı seviyelerde farklı amaçları hedeflemektedir. Bu programın ortaokul kısmının genel amacı ise: "Ortaokulu tamamlayan öğrencilerin, ilkokulda kazandıkları yetkinlikleri geliştirmek suretiyle millı̂ ve manevi değerleri benimsemiş, haklarını kullanan ve sorumluluklarını yerine getiren, 'Türkiye Yeterlilikler Çerçevesi'nde ve ayrıca disiplinlere özgü alanlarda ifadesini bulan temel düzey beceri ve yetkinlikleri kazanmış bireyler olmalarını sağlamak.” (MEB, 2019: 3) olarak ifade edilmiştir.

2018-2019 yllından itibaren uygulanmaya başlanan Türkçe Dersi Öğretim Programı'nda; programın önemi, perspektifi, ölçme-değerlendirme yaklaşımları, programda kazandırılması hedeflenen beceriler (ana dilinde iletişim, yabancı dillerle iletişim, bilim ve teknolojide temel yetkinlikler, dijital yetkinlik, öğrenmeyi öğrenme, sosyal ve vatandaşlıkla ilgili yetkinlikler, inisiyatif alma ve girişimcilik, kültürel farkındalık ve ifade ), öğrencilere temel dil becerileri ve dil bilgisinde kazandırılması hedeflenen davranışlar, öğretmen ve öğrencinin rolü, programda uygulanması gereken strateji ve yöntem ile birlikte programın yapısı detaylı bir şekilde açıklanmıştır (MEB, 2019).

Programların hazırlanmasındaki en önemli hedefler ise yenilenen kazanımlardır. Kazanımlar; öğretim programının yenilenmesinde, gelişen ve değişen eğitim-öğretim faaliyetlerinin uyumlu bir hâle gelmesinde temel belirleyicidir. Zira öğretim programında yer alan konuların nasıl, ne şekilde öğretileceğinin kapsamını ve sınılarını kazanımlar belirler (Çakmak \& Gürbüz, 2012). 1981 İlkokul Türkçe Dersi Müfredat Programında öğrencilere kazandırılması planlanan hedef ile öğrencide oluşturulması istenen davranış değişikliği olarak nitelendirilen ifadeler, 2005 Türkçe Öğretim Programı ile kazanım tanımını almış ve günümüzde kullanılan programlara kadar da bu şekilde süregelmiştir. Kazanım, öğrencinin eğitim yaşamı boyunca planlanmış bir program dâhilinde edinmesinin beklenildiği beceri ve istendik davranışlardır. Nuhoğlu, Başoğlu ve Kayganacıŏ̆lu, (2008: 182) ise kazanımları, Türkçe öğretiminde her beceri alanı için belirlenmiş somut hedefler olarak tanımlamışlardır. 2005 Türkçe Öğretim Programında da kazanım konusu, öğretim sürecinde öğrencilerin edinecekleri bilgi, beceri ve alışkanlıkları kapsamaktadır. Öğrencilerin okuma, dinleme, konuşma, yazma ve dil bilgisi beceri alanlarındaki gelişimleri ise bu kazanımların edinilmesine bağlıdır.

Eğitim bilimlerinde soruların ve kazanımların dağılımlarını ve bilişsel düzeylerini belirlemek için kullanılan bazı ölçütler vardır. Bloom Taksonomisi, MATH Taksonomisi bunlardan bazılarıdır. Webb (2009) tarafından alanyazına kazandırılan bilgi derinliği seviyeleri ise, bir sınıflandırma olmanın ötesinde bilginin derinliğine odaklanan bir yapıdır. Sunduğu bu yapı olanakları sayesinde bilgi derinliği seviyelerinin farklı hedeflere dönük sınavlarda, soruların oluşturulması ve bunlara dair formlar hazırlanması sürecinde kullanımının geçerli ve güvenilir sonuçlar vereceği düşüncesi git gide kuvvetlenmektedir (Özden, Akgün, Çinici vd. 2014: 93). Webb’in bilgi derinliği taksonomisinin dört seviyesi vardır. Bunlar:

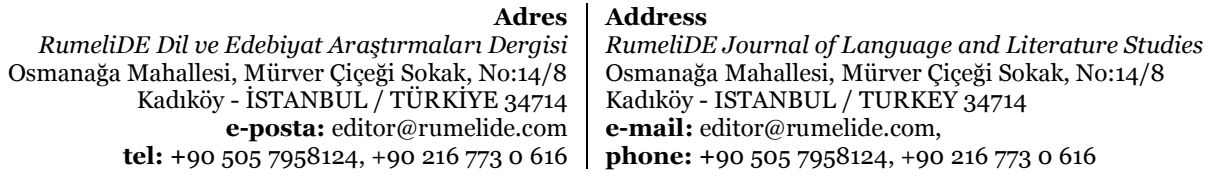

tel: +90 505 7958124, +90 2167730616 
The knowledge of Webb's knowledge of the achievements in the Turkish Language Teaching Program analysis by depth levels / A. Karabulut; M. Tunagür (pp. 15-29)

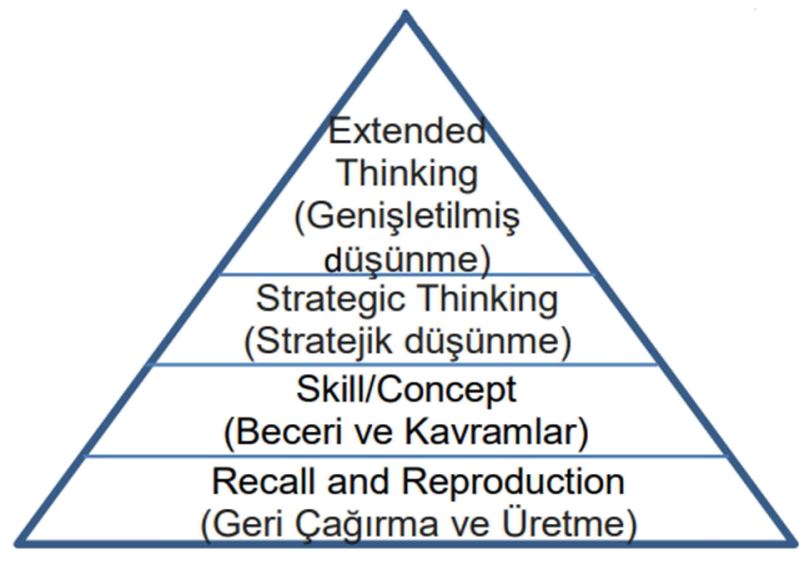

Webb’in Bilgi Derinliği Taksonomisi

olarak sınıflandırılmıştır (Webb, 2002: 1-2). Bu sınıflandırmanın her bir seviyesi şu şekilde özetlenebilir.

Seviye 1- Hatırlama: Bir bilgiyi hatırlama ve uzun süreli bellekten geri çağırmayı kapsar. Anahtar kelimeleri: listele, tanımla ve belirle olarak tanımlanmıştır. Bu seviyede öğrenci, sorunun cevabını biliyor ya da bilmiyordur. Cevabın bulunması adına zihinsel işlemler ve uygulamalar yapılmasına gerek yoktur. Tanımlamak, ezberlemek, okumak, hatırlamak, $5 \mathrm{~N} 1 \mathrm{~K}$ etkinlikleri bu seviyenin kapsamına girmektedir.

Seviye 2- Yetenek ve Kavramlar: Birinci seviyede var olan bilginin iki veya daha fazla işlemle kullanılmasını kapsar. Bu basamakta daha çok; şahısların, olayların, yerlerin ve kavramların karşılaştıılması, sınıflandırılması veya problemin ne olduğuna dair tanımlaması yapılır. Bu seviyede cevap, zihinsel işlemlerden geçirilerek verilir. Seviye 2'nin zihinsel kodları: özetle, tahmin et, organize et, sınıflandır ve ayırt et olarak belirlenmiştir. Sınıflandırmak, karşlaş̧ırmak, anlamlandırmak, yorumlamak, bağlamın ipuçlarını kullanmak, özetlemek bu seviyenin içerisinde kullanılan fiillerdir.

Seviye 3- Stratejik Düşünme: Üst düzey düşünme becerisi ile kısa bir zaman diliminde birden fazla cevabı analiz ederek bir sonuca varma basamağıdır. Bu seviyede, zihindeki cevapla gerçek cevabın kısa bir süre içinde analizi ve değerlendirmesi yapılır. Stratejik düşünmenin belirgin ifadeleri şunlardır: analiz, açıklama, bir dayanakla ispat etme, tüme varma ve yaratma. İletmek, değerlendirmek, eleştirmek, sonuca varmak, araştırmak bu seviyede beklenen fiillerdir.

Seviye 4- Geniş Düşünme: Geniş bir süreçte birçok basamak içerisinden düşünmeyi ve ileri düzeyde araştırma yapmayı kapsar. Genellikle bir projeye dayandırıldığından yaparak yaşayarak öğrenme evresini kapsar. Bu seviyedeki programın ögeleri planlamaların;yansıma, sentez, değerlendirme gibi üst düzey düşünme becerilerin daha derinleştirilmesini gerektirir. Öğrenciler tahmin edilemeyen sonuçlarla gerçek dünya problemlerini çözmek için araştırmaları yönetmeyle uğraştırılır. Var olan hedefe ulaşmak için uzunca bir zaman diliminde planlı olarak çalışmalar yapma ve sürdürme bu basamağın kodlarındandır. Bu seviyenin belirgin anahtar kelimeleri şunlardır: sentezlemek, iletmek ve başarmaktır. Analiz, sentez, kavramları uygulama, eleştiri oluşturma, yargıya varma bu basamağın içerdiği fiillerdir. 
$\mathrm{Bu}$ araştırmada, Milli Eğitim Bakanlığı tarafından 2018-2019 yılı itibari ile uygulamaya konulan Türkçe Öğretim Programı'nın ortaokul seviyesindeki kazanımlarının $(5,6,7,8)$ Webb 'in Bilgi Derinliği Seviyelerine göre analizinin yapılması amaçlanmıştır. Ülkemizde öğretim programlarının analizine yönelik çalışmalar yer almaktadır. Balcı, Coşkun ve Tamer (2012) tarafından yapılan araştırmada, Cumhuriyet Dönemi Türkçe Dersi Öğretim Programları'nın genel amaçları bakımından değerlendirilmesi amaçlanmış ve bu doğrultuda programlar, dil becerileri amaçlarına göre incelenmiştir. Aktürkoğlu (2005) ise 2004 yayımlanıp 2005 yılında uygulamaya konulan İlköğretim Türkçe Öğretim Programı ve Kılavuzu ile 1981 yılında hazırlanan Türkçe Programı'nın benzerliklerini ve farklılıklarını karşılaştıılarak değerlendirilmiştir. Durukan da (2013) öğretmen görüşleri açısından Türkçe Dersi Öğretim Programı kazanımlarını incelemiş ve kazanımları dil becerilerine sınıflandırarak uygun olup olmadıkları hakkında görüşler almıştır. Büyükalan Filiz ve Yıldırım (2019) ise Türkçe dersi kazanımlarını yenilenmiş Bloom Taksonomisine göre ele almışlardır.

Webb’in bilgi derinliği ile analizlerin yapıldığı çalışmalara daha fazla matematik alanında rastlanmaktadır. Şengül ve Işık (2014) 8. sınıf öğrencilerinin üst bilişsel becerilerinin Webb’in Bilgi Derinliği Seviyelerine dönük soruları çözme sürecini incelemiştir. Üregen, Oral \& Özkirişçi (2011) ise 2007- 2008 eğitim öğretim yllına ait 8. Sınıf OKS matematik sorularının analizini yapmıştır. Birinci (2014) tarafından ise, 2013-2014 öğretim yılında ilk defa uygulanan MSOS matematik soruları Webb’in Bilgi Derinliği çerçevesinde analiz edilmiştir.

Bu çalışmada ise literatürdekilerden farklı olarak Türkçe Dersi Öğretim Programı kazanımları Webb’in Bilgi Derinliğine göre ilk defa analiz edilmiştir. Çalışmadan elde edilen bulguların Bloom Taksonomisi çalışmaları ile karşılaştırılmasına ve her iki sınıflamanın alanyazına farklı bir bakış açısına olanak sunacağı düşünülmektedir. Araştırma 2019 Türkçe Dersi Öğretim Programı'ndaki kazanımların Webb’in Bilgi Derinliği Seviyeleri açısından değerlendirilmesi amacıyla gerçekleştirilmiştir. Bu doğrultuda 2019 Türkçe Dersi Öğretim Programı'ndaki kazanımlar, Webb’in Bilgi Derinliği Seviyeleri bakımından nasıldır?” sorusu araştırmanın ana problem sorusu olup aşağıdaki problem sorularına yanıt aranmaya çalışılmıştır.

- 5. sınıf Türkçe dersi kazanımları, Webb’in bilgi derinliği seviyeleri bakımından dil becerileri ve genel olarak nasıldır?

- 6. sınıf Türkçe dersi kazanımları, Webb’in bilgi derinliği seviyeleri bakımından dil becerileri ve genel olarak nasıldır?

- 7. sınıf Türkçe dersi kazanımları, Webb’in bilgi derinliği seviyeleri bakımından dil becerileri ve genel olarak nasıldır?

- $\quad$ 8. sınıf Türkçe dersi kazanımları, Webb’in bilgi derinliği seviyeleri bakımından dil becerileri ve genel olarak nasıldır?

\section{Yöntem}

\section{Araşturmanın modeli}

Çalışma nitel araştırma yöntemine göre gerçekleştirilmiştir. Nitel araştırma; sosyal olguları bağlı oldukları ve içinde bulundukları ortamları gözlem, görüşme ya da belgeleri değerlendirmek yoluyla bilgi edinme ve bu bilgileri analiz ederek kuram geliştirme olarak tanımlanabilir (Özdemir, 2010). Nitel araştırmada üç tür bilgi toplama yöntemi yaygın olarak kullanılmaktadır: Görüşme, gözlem ve yazılı dokümanların incelenmesi. Bu araştırmada doküman incelemesi yöntemi tercih edilmiştir. Doküman incelemesi, incelenmesi amaçlanan olgu ve olaylar hakkında bilgi içeren yazılı materyallerin

\footnotetext{
\begin{tabular}{r|l} 
Adres & Address \\
RumeliDE Dil ve Edebiyat Araşttrmaları Dergisi & RumeliDE Journal of Language and Literature Studies
\end{tabular} Osmanağa Mahallesi, Mürver Çiçeği Sokak, No:14/8 Osmanağa Mahallesi, Mürver Çiçeği Sokak, No:14/8 Kadıköy - İSTANBUL / TÜRKIYE 34714 Kadıköy - ISTANBUL / TURKEY 34714 e-posta: editor@rumelide.com e-mail: editor@rumelide.com, tel: +90 505 7958124, +90 2167730616 phone: +90 505 7958124, +90 2167730616
} 
The knowledge of Webb's knowledge of the achievements in the Turkish Language Teaching Program analysis by depth levels / A. Karabulut; M. Tunagür (pp. 15-29)

analizidir. Bowen; doküman incelemesini, hem basılı hem de elektronik materyalleri incelemek veya değerlendirmek için sistematik bir işlem olarak tanımlamaktadır (2009: 27). Bu bağlamda, Webb’in bilgi derinliği ile ilgili literatür taraması yapılarak tematik çerçeve oluşturulmuş, ardından 2019 Türkçe Dersi Öğretim Programı’nda yer alan 5, 6, 7 ve 8. sınıfa ait kazanımlar liste hâlinde çıkarılmıştır. Her bir kazanım Webb’in Bilgi Derinliği Seviyelerine uygun oldukları bir veya birden fazla seviye ile kodlanmıştır.

\section{Veri toplama aracı}

Çalışmanın materyalini (veri toplama aracı) 2019 yılında yayımlanan Türkçe Dersi Öğretim Programı oluşturmaktadır. Bu kapsamda Türkçe Dersi Öğretim Programının ikinci kademe 5, 6, 7 ve 8.sınıflarına ait kazanımları Webb’in bilgi derinliği seviyelerine göre incelenmiştir.

\section{Verilerin analizi}

Araştırmada elde edilen veriler içerik analiz yöntemi ile analiz edilmiştir. Bu analiz türünde amaç, elde edilen verileri açıklayacak kavram ve bağıntılara ulaşmaktır. İçerik analizi ile birbirine benzeyen veriler belirli kavramlar ve temalar çerçevesinde bir araya getirilerek okurların anlayabileceği bir şekilde yorumlanarak sunulur. (Yıldırım ve Şimşek, 2008).

\section{Bulgular}

2019 Türkçe Dersi Öğretim Programı'nda kazanımlar, dört temel dil becerisi başlığında; dinleme/izleme, konuşma, okuma ve yazma olarak verilmiştir. Bu çalışmada ise ortaokul kısmına ait Türkçe dersi kazanımları incelenmiş ve her bir kazanımın hangi bilgi derinliği seviyesine yönelik olduğu belirlenmiştir.

\section{Sinıf kazanımlarına ait bulgular}

Bu bölümde 5. sınıf dil becerilerine ait kazanımlar, ilk aşamada ayrı tablolar olarak çıkarılmış, hemen ardından kazanımların sınıf bazında genel bulguları verilmiştir. Elde edilen bulgular beş tabloda sunulmuş, bu sınıf seviyesinin genel kazanımlarını içeren tabloda ise kazanımlara ve bilgi seviyelerine dönük bulgular aktarılarak yorumlanmıştır.

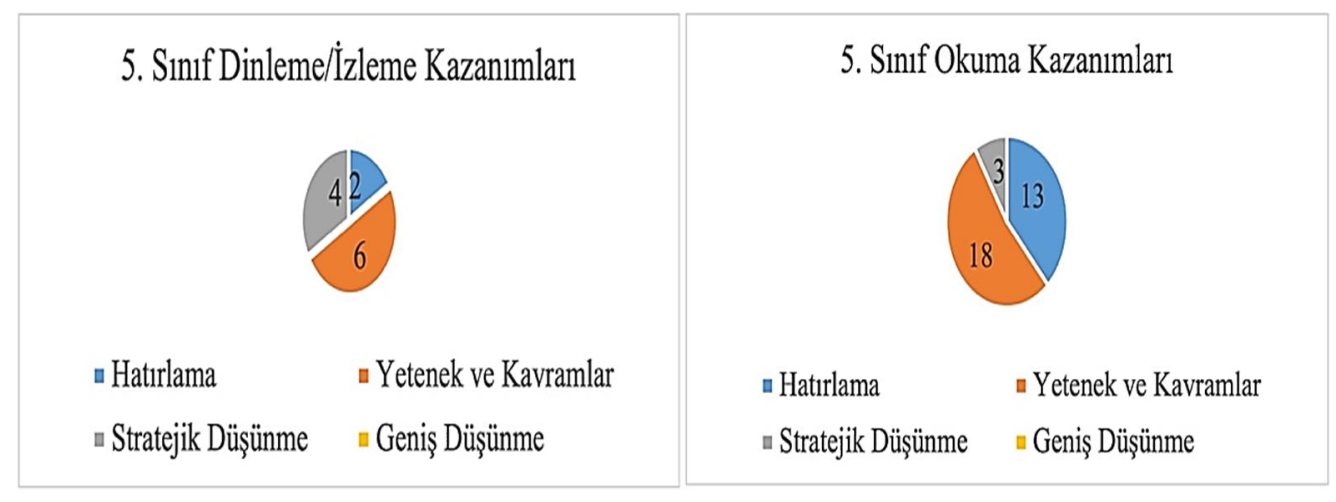

\footnotetext{
\begin{tabular}{r|l} 
Adres & Address \\
RumeliDE Dil ve Edebiyat Araşttrmalar Dergisi & RumeliDE Journal of Language and Literature Studies
\end{tabular} Osmanağa Mahallesi, Mürver Çiçeği Sokak, No:14/8 $\quad$ Osmanağa Mahallesi, Mürver Çiçeği Sokak, No:14/8 Kadıköy - İSTANBUL / TÜRKIYE 34714 Kadıköy - ISTANBUL / TURKEY 34714 e-posta: editor@rumelide.com e-mail: editor@rumelide.com, tel: +90 505 7958124, +90 2167730616 phone: +90 505 7958124, +90 2167730616
} 


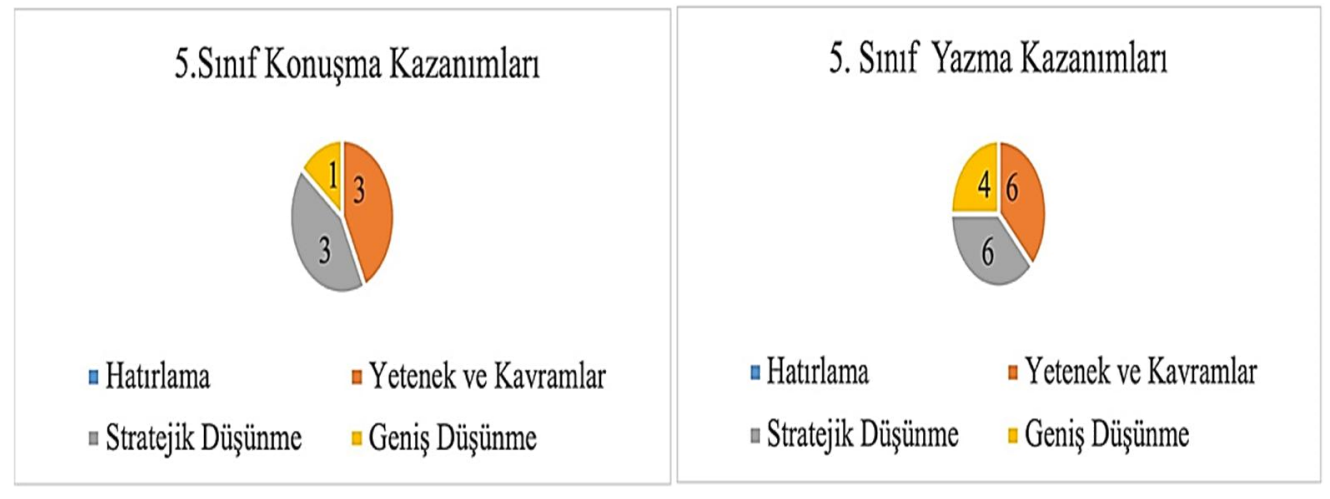

Şekil 1: 5. Sınıf Kazanımlarının Dil Becerilerine Göre Analizi

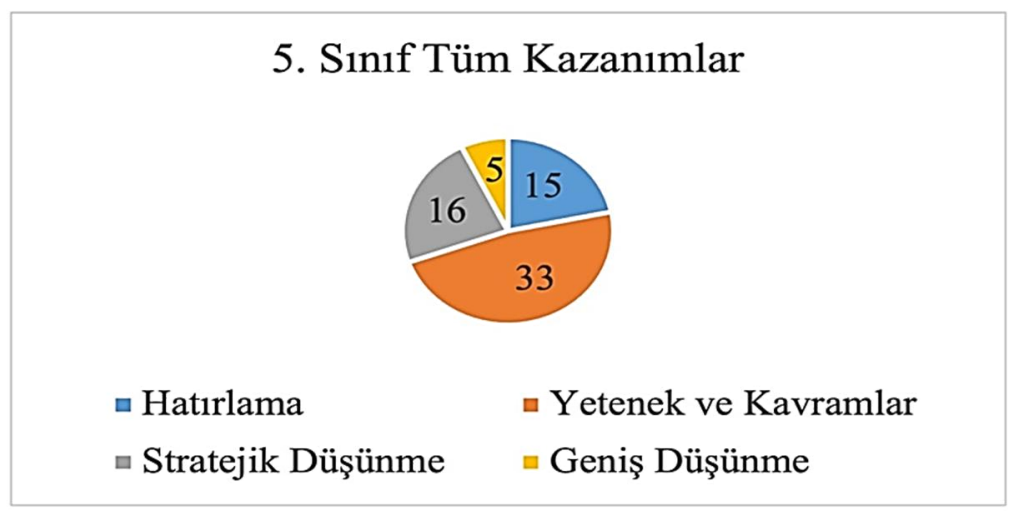

Şekil 2: 5. Sınıf Kazanımlarının Webb’in Bilgi Derinliği Seviyelerine Göre Analizi

Şekil 2'de görüldügüu gibi, Türkçe dersi 5. sınıf kazanımları; \%47 (33) beceriler/kavramlar, \%23 (16) stratejik düşünme, \%22 (15) hatırlama/yeniden üretme ve \%8 (5) geniş düşünme seviyesindedir.

Tablo 1: Webb’in Bilgi Derinliği Seviyelerine Göre 5. Sınıf Kazanımları

Kazanımın Beceri Kazanım

Alanı ve Seviyesi

5. Sinif

Dinleme/İzleme

5. Sinif Konuşma

5. Sinif Okuma verir. kullanır. kullanir.
T.5.1.6. Dinledikleri/izlediklerine yönelik sorulara cevap

T.5.1.3. Dinlediklerinin/izlediklerinin konusunu belirler.

T.5.1.12. Dinleme stratejilerini uygular.

T.5.2.3. Konuşma stratejilerini uygular.

T.5.2.6. Konuşmalarında uygun geçiş, ve bağlantı ifadelerini

T.5.2.7. Konuşmalarında yabancı dillerden alınmış, dilimize henüz yerleşmemiş, kelimelerin Türkçelerini

T.5.3.2. Metni türün özelliklerine uygun biçimde okur.

T.5.3.4. Okuma stratejilerini kullanır.
Webb Bilgi Derinliği

Seviyesi

Hatırlama/Yeniden Üretme-Seviye 1

Yetenek ve KavramlarSeviye 2

Stratejik DüşünmeSeviye 3

Stratejik DüşünmeSeviye 3

Yetenek ve KavramlarSeviye 2

Hatırlama/Yeniden Üretme-Seviye 1

Yetenek ve KavramlarSeviye 2

Stratejik Düşünme-

\begin{tabular}{r|l} 
Adres & Address \\
RumeliDE Dil ve Edebiyat Araştırmaları Dergisi & RumeliDE Journal of Language and Literature Studies \\
Osmanağa Mahallesi, Mürver Çiçeği Sokak, No:14/8 & Osmanağa Mahallesi, Mürver Çiçeği Sokak, No:14/8 \\
Kadıköy - İSTANBUL / TÜRKIYE 34714 & Kadıköy - ISTANBUL / TURKEY 34714 \\
e-posta: editor@rumelide.com & $\begin{array}{l}\text { e-mail: editor@rumelide.com, } \\
\text { phone: +90 505 7958124, +90 } 2167730616\end{array}$
\end{tabular}


The knowledge of Webb's knowledge of the achievements in the Turkish Language Teaching Program analysis by depth levels / A. Karabulut; M. Tunagür (pp. 15-29)

5. Sinif Yazma

T.5.3.15. Metinde ele alınan sorunlara farklı çözümler üretir.

T.5.4.2. Bilgilendirici metin yazar.

T.5.4.4. Yazma stratejilerini uygular.

T.5.4.8. Sayıları doğru yazar.
Seviye 3

Stratejik Düşünme-

Seviye 3

Geniş Düşünme-Seviye 4

Stratejik DüşünmeSeviye 3

Hatırlama/Yeniden Üretme-Seviye 1

Tablo 1'de görüldüğü gibi Webb’in bilgi seviyesine göre 5. sınıf kazanımları yer almaktadır. Tüm kazanımlar yerine her beceriden birkaç kazanım örneğine yer verilmiştir. Örnek kazanımlar verilirken her bir bilgi seviyesinden örnekler verilmeye, dil becerilerinin hepsinden kazanım aktarmaya ve farklı sınıf seviyelerinde aynı kazanımları örnek vermemeye çalışılmıştır. Bu bağlamda, 5. sınıf kazanımlarının hatırlama/yeniden üretme, yetenek ve kavramlar ile stratejik düşünme ve geniş düşünme açısından 1, 2, 3 ve 4.seviyelere göre analizi yapılarak kazanım örneklerine yer verilmiştir.

\section{Sinıf kazanımlarına ait bulgular}

Bu bölümde 6. sınıf dil becerilerine ait kazanımlar, ilk aşamada ayrı tablolar olarak çıkarılmış, hemen ardından kazanımların sınıf bazında genel bulguları verilmiştir. Elde edilen bulgular beş tabloda sunulmuş, bu sınıf seviyesinin genel kazanımlarını içeren tabloda ise kazanımlara ve bilgi seviyelerine dönük bulgular aktarılarak yorumlanmıştır.

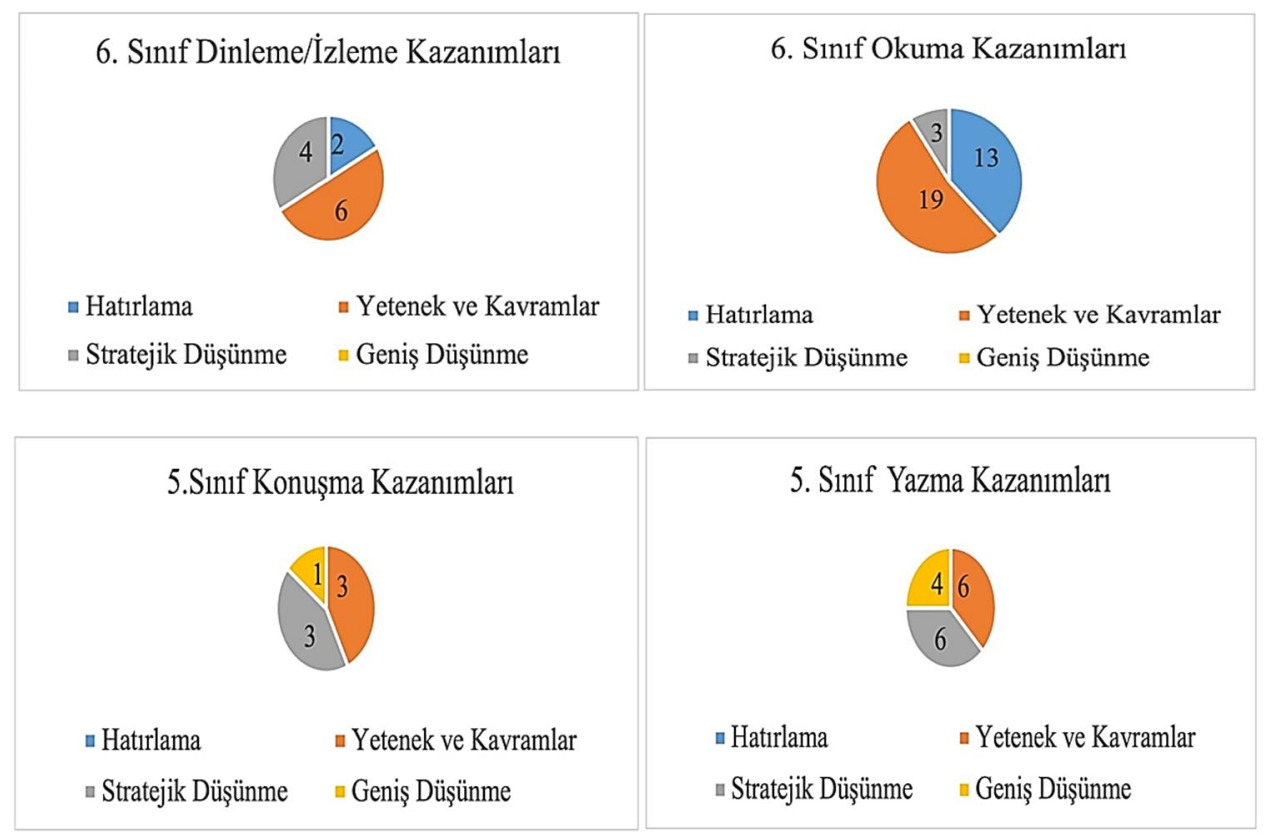

Şekil 3: 6. Sınıf Kazanımlarının Dil Becerilerine Göre Analizi

\begin{tabular}{r|l} 
Adres & Address \\
RumeliDE Dil ve Edebiyat Araşttrmalar Dergisi & RumeliDE Journal of Language and Literature Studies \\
Osmanağa Mahallesi, Mürver Çiçeği Sokak, No:14/8 & Osmanağa Mahallesi, Mürver Çiçeği Sokak, No:14/8 \\
Kadıköy - İSTANBUL / TÜRKIYE 34714 & Kadıköy - ISTANBUL / TURKEY 34714 \\
e-posta: editor@rumelide.com & e-mail: editor@rumelide.com, \\
tel: +90 505 7958124, +90 216 773 o 616 & phone: +90 505 7958124, +90 2167730616
\end{tabular}




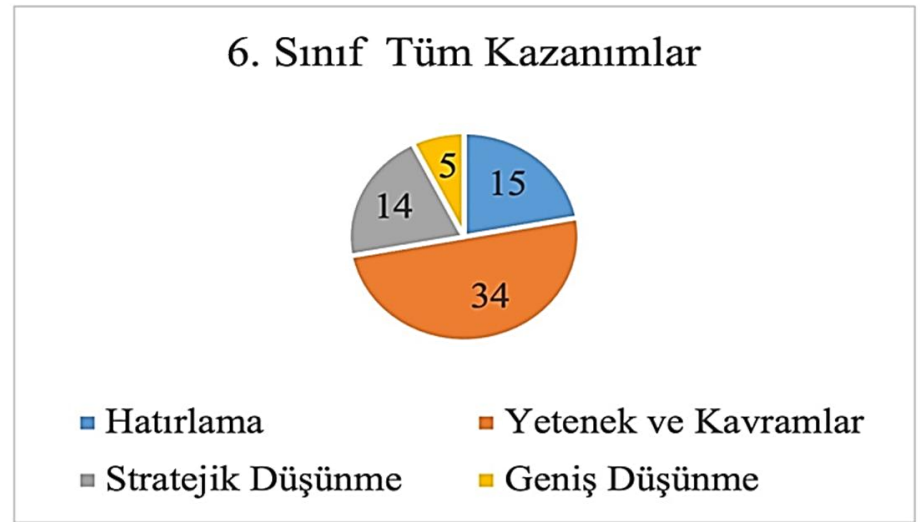

Şekil 4: 6. Sınıf Kazanımlarının Webb’in Bilgi Derinliği Seviyelerine Göre Analizi.

Şekil 4 incelendiğinde, Türkçe dersi 6. sınıf kazanımlarının \%50'sinin (34) beceriler/kavramlar seviyesinde, \%22'sinin (15) hatırlama/yeniden üretme, \%21'inin (14) stratejik düşünme ve \%7'sinin ise (5) geniş düşünme seviyesinde olduğu görülmektedir.

Tablo 2: Webb’in Bilgi Derinliği Seviyelerine Göre 6. Sınıf Kazanımları

Kazanımın Beceri Alanı ve Kazanım Seviyesi

6. Sinıf Dinleme/İzleme

6. Sinıf Konuşma

6. Sinıf Okuma

6. Sinif Yazma kullanır. eder. yapar.
T.6.1.6. Dinlediklerinin/izlediklerinin ana fikrini/ana duygusunu tespit eder.

T.6.1.9. Konuşmacının sözlü olmayan mesajlarını kavrar.

T.6.1.10. Dinlediklerinin/izlediklerinin içeriğini değerlendirir.

T.6.2.1. Hazırlıklı konuşma yapar.

T.6.2.2. Hazırlıksız konuşma yapar.

T.6.2.5. Kelimeleri anlamlarına uygun

T.6.3.17. Metinle ilgili soruları cevaplar.

T.6.3.7. Çekim eklerinin işlevlerini ayırt

T.6.3.25. Metinler arasında karşılaştırma

T.6.4.3. Hikâye edici metin yazar.

T.6.4.5. Yazdıklarını desteklemek için gerektiğinde grafik ve tablo kullanır.

T.6.4.6. Bir işi işlem basamaklarına göre yazar.
Webb Bilgi Derinliği Seviyesi

Yetenek ve Kavramlar-Seviye 2

Yetenek ve Kavramlar-Seviye 2

Stratejik Düşünme-Seviye 3

Yetenek ve Kavramlar-Seviye 2

Stratejik Düşünme-Seviye 3

Yetenek ve Kavramlar-Seviye 2

Hatırlama/Yeniden ÜretmeSeviye 1

Yetenek ve Kavramlar-Seviye 2

Yetenek ve Kavramlar-Seviye 2

Geniş Düşünme-Seviye 4

Stratejik Düşünme-Seviye 3

Yetenek ve Kavramlar-Seviye 2

Tablo 2'de görüldüğü gibi Webb'in bilgi seviyesine göre 6. sınıf kazanımları yer almaktadır. Tüm kazanımlar yerine her beceriden birkaç kazanım örneğine yer verilmiştir. 6. sınıf kazanımlarının hatırlama/yeniden üretme, yetenek ve kavramlar ile stratejik düşünme ve geniş düşünme açısından 1 , 2, 3 ve 4. seviyelere göre analizi yapılarak kazanım örneklerine yer verilmiştir.

\begin{tabular}{r|l} 
Adres & Address \\
RumeliDE Dil ve Edebiyat Araştırmalar Dergisi & RumeliDE Journal of Language and Literature Studies \\
Osmanağa Mahallesi, Mürver Çiçeği Sokak, No:14/8 & Osmanağa Mahallesi, Mürver Çiçeği Sokak, No:14/8 \\
Kadık̈y - İSTANBUL / TÜRKIYE 34714 & Kadıköy - ISTANBUL / TURKEY 34714 \\
e-posta: editor@rumelide.com & e-mail: editor@rumelide.com, \\
tel: +90 505 7958124, +90 216 773 o 616 & phone: +90 505 7958124, +90 2167730616
\end{tabular}


The knowledge of Webb's knowledge of the achievements in the Turkish Language Teaching Program analysis by depth levels / A. Karabulut; M. Tunagür (pp. 15-29)

\section{Sinıf kazanımlarına ait bulgular}

Bu bölümde 7. sınıf dil becerilerine ait kazanımlar, ilk aşamada ayrı tablolar olarak çıkarılmış, hemen ardından kazanımların sınıf bazında genel bulguları verilmiştir. Elde edilen bulgular beş tabloda sunulmuş, bu sınıf seviyesinin genel kazanımlarını içeren tabloda ise kazanımlara ve bilgi seviyelerine dönük bulgular aktarılarak yorumlanmıştır.

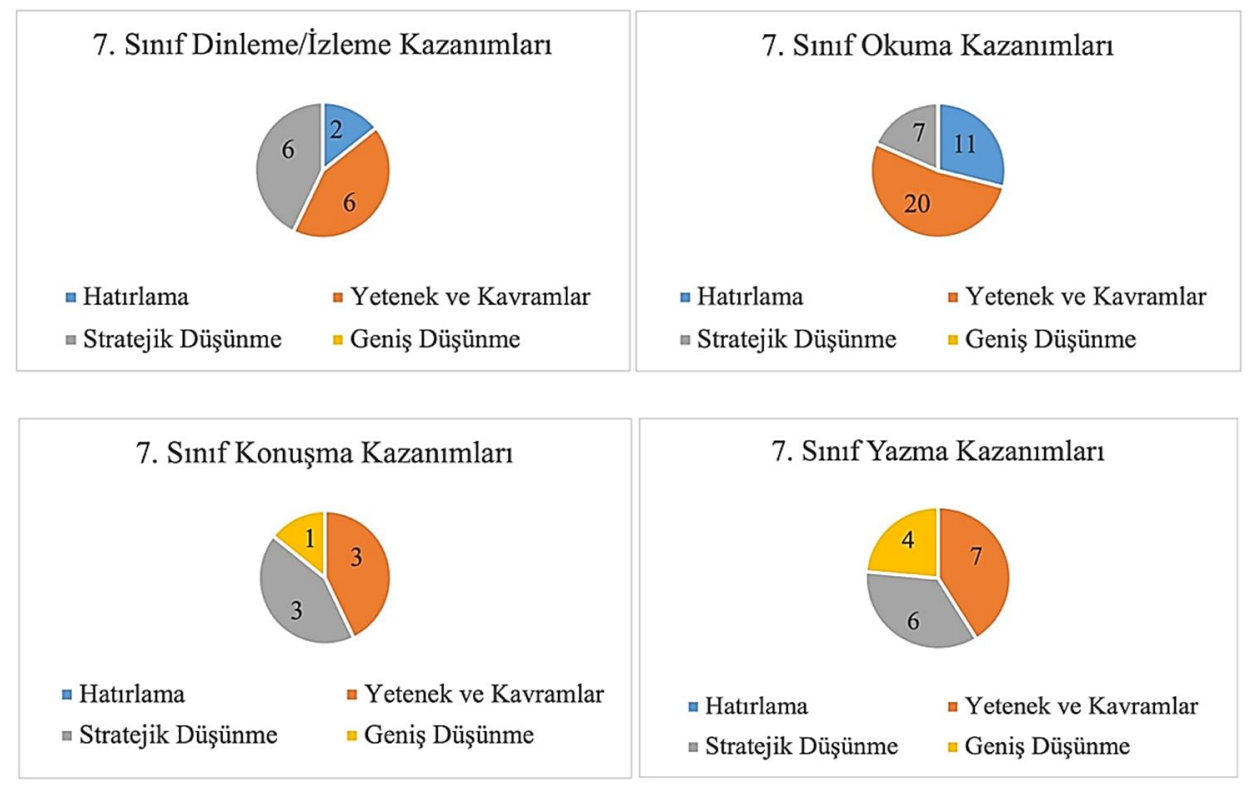

Şekil 5: 7. Sınıf Kazanımlarının Dil Becerilerine Göre Analizi.

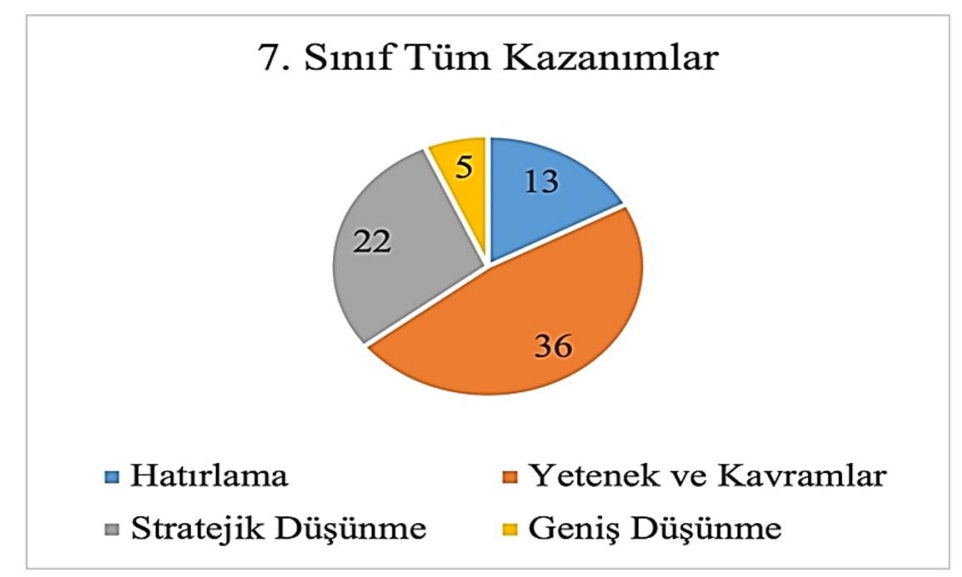

Şekil 6: 7. Sınıf Kazanımlarının Webb’in Bilgi Derinliği Seviyelerine Göre Analizi.

Şekil 6 incelendiğinde, Türkçe dersi 7. sınıf kazanımlarının \%47'sinin (36) beceriler/kavramlar seviyesinde, \%29'unun (22) stratejik düşünme, \%17'sinin (13) hatırlama/yeniden üretme ve \%7'sinin (5) geniş düşünme seviyesinde olduğu görülmektedir. 
Tablo 3: Webb’in Bilgi Derinliği Seviyelerine Göre 7. Sınıf Kazanımları

$\begin{array}{lll}\begin{array}{l}\text { Kazanımın Beceri Alanı ve } \\ \text { Seviyesi }\end{array} & \text { Kazanım } & \text { Webb Bilgi Derinliği Seviyesi } \\ \text { 7. Sınıf Dinleme/İzleme } & \begin{array}{l}\text { T.7.1.3. Dinlediklerini/izlediklerini özetler. } \\ \text { T.7.1.9. Dinlediklerinde/izlediklerinde } \\ \text { başvurulan düşünceyi geliştirme yollarını } \\ \text { tespit eder. }\end{array} & \begin{array}{l}\text { Yetenek ve Kavramlar-Seviye } 2 \\ \text { Seviye 1 }\end{array}\end{array}$

T.7.1.4. Dinledikleri/izlediklerine yönelik soruları cevaplar.

7. Sinıf Konuşma

T.7.2.3. Konuşma stratejilerini uygular.

T.7.2.5. Kelimeleri anlamlarına uygun kullanir.

T.7.2.6. Konuşmalarında uygun geçiş ve bağlantı ifadelerini kullanır.

7. Sinıf Okuma

7. Sinif Yazma
T.7.3.8. Metindeki söz sanatlarını tespit eder.

T.7.3.21. Metindeki hikâye unsurlarını belirler.

T.7.3.26. Metindeki gerçek ve kurgusal unsurları ayırt eder.

T.7.4.7. Yazılarını zenginleştirmek için atasözleri, deyimler ve özdeyişler kullanır.

T.7.4.14. Araştırmalarının sonuçlarını yazılı olarak sunar.

T.7.4.10. Formları yönergelerine uygun doldurur.
Hatırlama/Yeniden ÜretmeSeviye 1

Stratejik Düşünme-Seviye 3

Yetenek ve Kavramlar-Seviye 2

Yetenek ve Kavramlar-Seviye 2

Hatırlama/Yeniden Üretme-

Seviye 1

Hatırlama/Yeniden Üretme-

Seviye 1

Yetenek ve Kavramlar-Seviye 2

Yetenek ve Kavramlar-Seviye 2

Geniş Düşünme-Seviye 4

Yetenek ve Kavramlar-Seviye 2

Tablo 3’te görüldüğü gibi Webb’in bilgi seviyesine göre 7. sınıf kazanımları yer almaktadır. Tüm kazanımlar yerine her beceriden birkaç kazanım örneğine yer verilmiştir. 7. sınıf kazanımlarının hatırlama/yeniden üretme, yetenek ve kavramlar ile stratejik düşünme ve geniş düşünme açısından 1, 2, 3 ve 4. seviyelere göre analizi yapılarak kazanım örneklerine yer verilmiştir.

\section{Sinıf kazanımlarına ait bulgular}

Bu bölümde 8. sınıf dil becerilerine ait kazanımlar, ilk aşamada ayrı tablolar olarak çıkarılmış, hemen ardından kazanımların sınıf bazında genel bulguları verilmiştir. Elde edilen bulgular beş tabloda sunulmuş, bu sınıf seviyesinin genel kazanımlarını içeren tabloda ise kazanımlara ve bilgi seviyelerine dönük bulgular aktarılarak yorumlanmıştır.

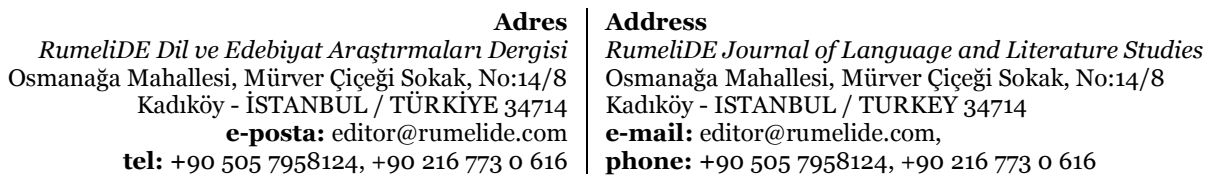

tel: +90 505 7958124, +90 216773 o 616

e-mail: editor@rumelide.com

phone: +90 $5057958124,+902167730616$ 
The knowledge of Webb's knowledge of the achievements in the Turkish Language Teaching Program analysis by depth levels / A. Karabulut; M. Tunagür (pp. 15-29)

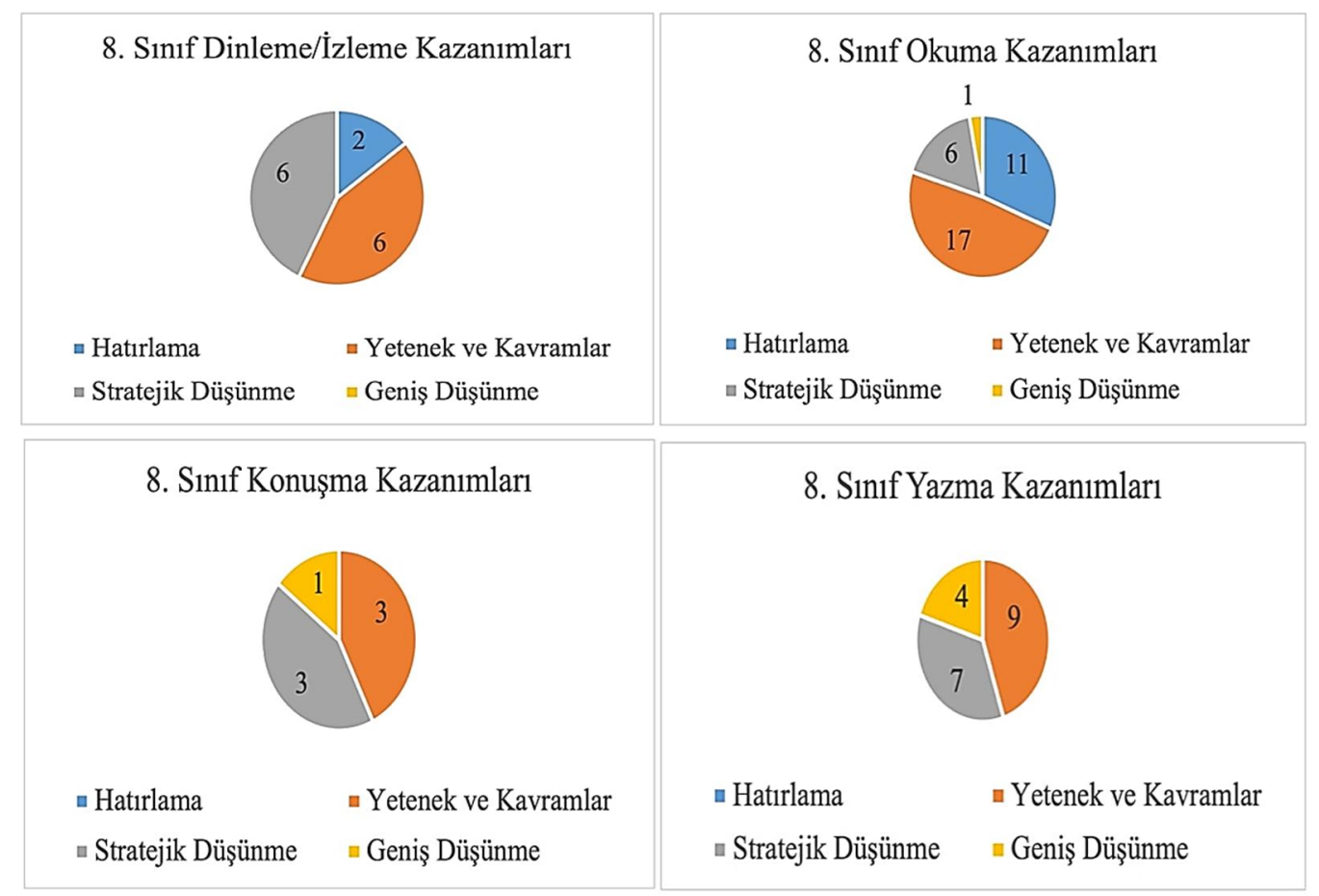

Şekil 7: 8. Sınıf Kazanımlarının Dil Becerilerine Göre Analizi

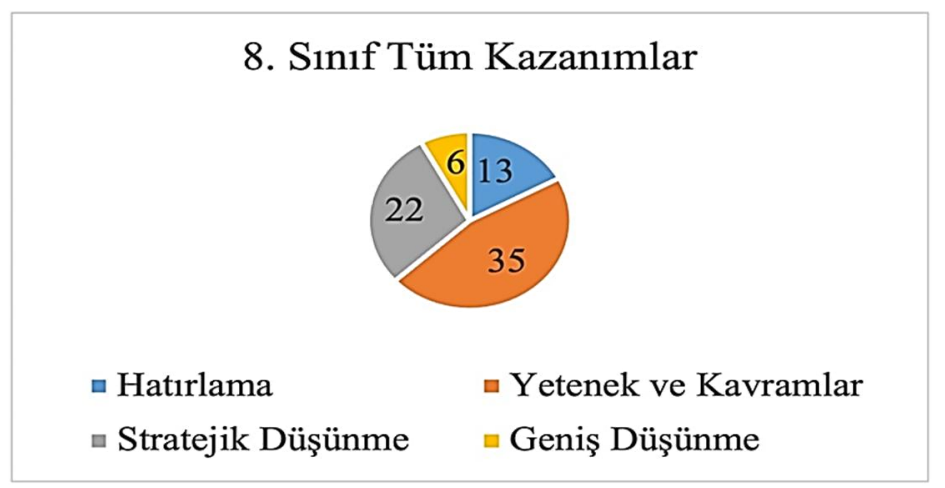

Şekil 8: 8. Sınıf Kazanımlarının Webb’in Bilgi Derinliği Seviyelerine Göre Analizi

Şekil 8 incelendiğinde, Türkçe dersi 8. sınıf kazanımlarının \%46’sının (35) beceriler/kavramlar seviyesinde, \%29'unun (22) stratejik düşünme, \%17'sinin (13) hatırlama/yeniden üretme ve \%8'inin (6) geniş düşünme seviyesinde olduğu görülmektedir.

Tablo 4: Webb’in Bilgi Derinliği Seviyelerine Göre 8. Sınıf Kazanımları

Kazanımın Beceri Alanı ve Kazanım Seviyesi

8. Sinıf Dinleme/İzleme
T.8.1.1. Dinlediklerinde/izlediklerinde geçen olayların gelişimi ve sonucu hakkında tahminde bulunur.

T.8.1.9. Dinlediklerinde/izlediklerinde tutarlılığı sorgular.

T.8.1.11. Dinledikleri/izledikleri medya metinlerini değerlendirir.
Webb Bilgi Derinliği Seviyesi

Yetenek ve Kavramlar-Seviye 2

Stratejik Düşünme-Seviye 3

Geniş Düşünme- Seviye 4
Adres

RumeliDE Dil ve Edebiyat Araşttrmalar Dergisi Osmanağa Mahallesi, Mürver Çiçeği Sokak, No:14/8

Kadıköy - İSTANBUL / TÜRKIYE 34714 e-posta: editor@rumelide.com

tel: +90 $5057958124,+902167730616$
Address

RumeliDE Journal of Language and Literature Studies

Osmanağa Mahallesi, Mürver Çiçeği Sokak, No:14/8

Kadıköy - ISTANBUL / TURKEY 34714

e-mail: editor@rumelide.com,

phone: +90 505 7958124, +90 2167730616 
8. Sınıf Konuşma

8. Sinif Okuma

8. Sinif Yazma
T.8.2.1. Hazırlıklı konuşma yapar.

T.8.2.4. Konuşmalarında beden dilini etkili bir şekilde kullanır.

T.8.2.5. Kelimeleri anlamlarına uygun kullanir.

T.8.3.25. Okudukları ile ilgili çıkarımlarda bulunur.

T.8.3.26. Metin türlerini ayırt eder.

T.8.3.29. Medya metinlerini analiz eder.

T.8.4.8. Yazılarında mizahi ögeler kullanır.

T.8.4.12. Kisa metinler yazar.

T.8.4.16. Yazdıklarını düzenler.
Yetenek ve Kavramlar-Seviye 2

Hatırlama/Yeniden ÜretmeSeviye 1

Hatırlama/Yeniden ÜretmeSeviye 1

Stratejik Düşünme-Seviye 3

Yetenek ve Kavramlar-Seviye 2

Geniş Düşünme- Seviye 4

Yetenek ve Kavramlar-Seviye 2

Yetenek ve Kavramlar-Seviye 2

Stratejik Düşünme-Seviye 3

Tablo 4'de görüldüğü gibi Webb’in bilgi seviyesine göre 8. sınıf kazanımları yer almaktadır. Tüm kazanımlar yerine her beceriden birkaç kazanım örneğine yer verilmiştir. 8. sınıf kazanımlarının hatırlama/yeniden üretme, yetenek ve kavramlar ile stratejik düşünme ve geniş düşünme açısından 1, 2, 3 ve 4. seviyelere göre analizi yapılarak kazanım örneklerine yer verilmiştir.

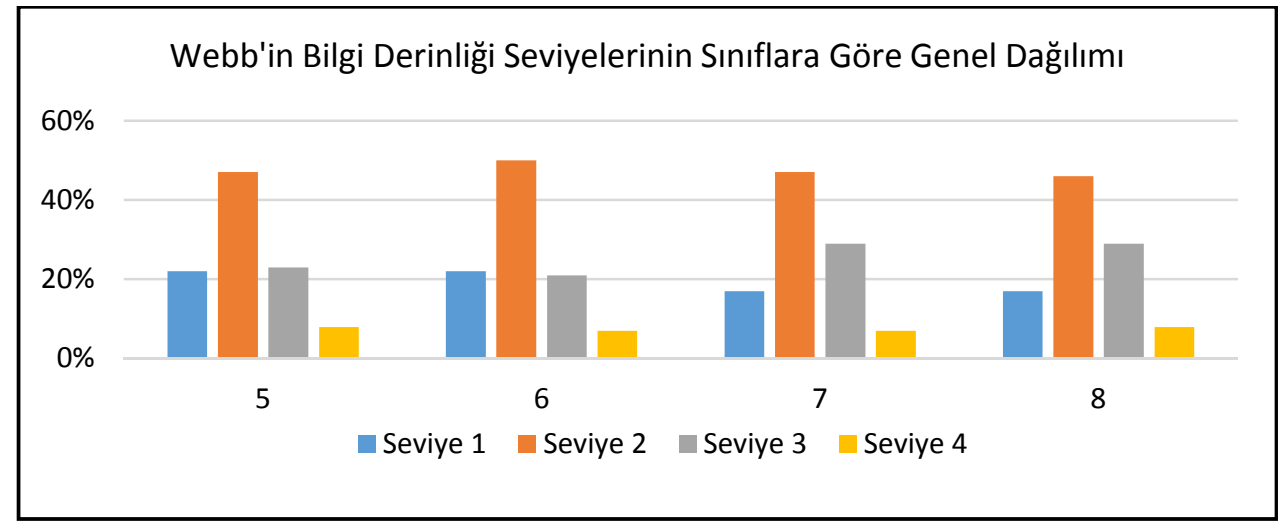

Şekil 9: Webb’in Bilgi Seviyelerinin Sınıflara Göre Yüzdelik Dağılımları

Şekil 9 incelendiğinde, sınıf bazında en fazla bilgi seviyesinin seviye 2'de toplandığı, bu bilgi seviyesini seviye 3 ve seviye 1’in takip ettiği görülmektedir. Webb’in bilgi derinliğinin en üst basamağı olan seviye 4'ün ise kazanımlarda çok az yer kapladığı sonucu ortaya çıkmaktadır. Tablodan çıkan bir başka sonuçta ise, 5 ile 6 . sınıf ve 7 ile 8 . sınıfın bilgi derinliği seviyelere göre yüzdelik ortalamalarının birbirlerine yakın oldukları görülmektedir. Bu bulguyu destekleyen başka bir sonuç da bu sınıf seviyelerinin kazanım sayılarının birbirlerine eşit olmasıdır.

Ayrıca bulgulardan gözlemlenen başka bir durum ise bilgi derinliği seviyelerinin sınıf seviyeleri ve dil becerileri bağlamında ele alındığında dinleme, okuma, yazma becerileri kazanımlarında 2. seviyede yoğunlaştığı görülürken konuşma becerisinde ise 2 ve 3. seviyeye ortak dağıldığıdır.

\section{Sonuç ve tartışma}

Yapılan çalışmada, 2019 eğitim öğretim yılı itibarıyla uygulamaya konulan Türkçe Öğretim Programı incelenmiş ve bu programın ortaokul kısmında yer alan dil becerilerine ait kazanımlar Webb'in bilgi derinliği seviyelerine göre analiz edilmiştir. Yapılan değerlendirilmede, Türkçe Dersi Programında yer 
The knowledge of Webb's knowledge of the achievements in the Turkish Language Teaching Program analysis by depth levels / A. Karabulut; M. Tunagür (pp. 15-29)

alan ortaokul seviyesi kazanımlarının \% 50'sinin 2. seviyede, \%25'inin 3. seviyede, kazanımların \%20'sinin 3. seviyede ve son olarak da \%5'inin 4. Seviyede dağılım gösterdiğine ulaşılmıştır. Elde edilen bulgular kazanımların genellikle 2. seviye yani yetenekler ve kavramlar kısmında yığılma gösterdiğini, stratejik düşünmeye yönelik kazanımların \% 20, geniş düşünmeye dönük kazanımların ise sadece \% 5 seviyesinde dağılım göstermesi, programın üst düzey düşünme becerilerine çok fazla yer ayırmadığını göstermektedir.

İlgili litetatürde Türkçe Öğretim Programı'nda yer alan kazanımların ya da sınav sorularının Webb’in Bilgi Derinliği seviyesine göre analiz edildiği herhangi bir araştırmaya rastlanılmamıştır. Fakat Webb’in Bilgi Derinliği Seviyesine göre analiz edilen sınav soruları ve öğretim programlarında yer alan kazanımlarla ilgili araştırmalar bulunmaktadır. Bu kapsamda Şengül ve Işılk (2014) 8.sınıf öğrencilerinin üst bilişsel becerilerinin Webb’in Bilgi Derinliği Seviyelerine ilişkin problemleri çözme açısından inceledikleri araştırmalarında, 8. sınıf öğrencilerinin üst bilişsel becerilerinin matematiksel problemlerinin çözümünde etkili olduğu bulgusuna ulaşmışlardır. Birinci (2014) matematik sorularını Webb’in Bilgi Derinliği seviyesinde analiz etmiş ve soruların bazı öğrenme alanlarını kapsamadığı ve soruların da alt seviyelerde yer aldığı sonucuna erişmiştir. Özden vd. (2014), ortak sınavlarda yer alan fen bilimleri sorularının Webb’in Bilgi Derinliği Seviyelerine göre analiz ettikleri çalışmasında soruların daha çok seviye 1 ve seviye 2'de yoğunlaştığı seviye 3'te ise soruların daha az yer aldığı sonucuna ulaşmıştır. Eke (2016) ise fizik dersi öğretim programında yer alan kazanımları Webb’in Bilgi Derinliği Seviyelerine göre analiz ettiği araştırmasında 9. sınıf kazanımlarının Webb’in Bilgi Derinliği Seviyesine daha çok uyduğunu; 10, 11 ve 12. sınıf öğretim programı kazanımlarının daha az uyumlu olduğu sonucuna ulaşmıştır. Yapılan bu araştırmaların sonuçları ile araştırmamızın sonuçlarının örtüştüğü görülmektedir.

2019 Türkçe Öğretim Programı ortaokul kısmında yer alan dil becerilerine ait kazanımların Webb’in Bilgi Derinliği Seviyelerine göre analiz edilmesinin amaçlandığı bu araştırmada, sınıflar arasında kazanımların dengeli bir şekilde dağılmadı̆̆ı ve seviyelere göre kazanımlarda eşit dağılımın yapılmadığı sonucuna ulaşılmıştır. Bu sonuçlar doğrultusunda şu önerilerde bulunulabilir:

- Ulusal ve uluslarası ölçekte yapılan sınavlarda sorulan Türkçe sorularının Webb’in bilgi derinliği seviyeleri dikkate alınarak hazırlanabilir,

- $\quad$ Öğretim programının hedeflediği amaç, kazanım ve derslerde sorulan sorular arasında Webb’in Bilgi Derinliği Seviyelerine göre analizler yapılarak aralarındaki ilişkiler incelenebilir.

\section{Kaynakça}

Aktürkoğlu, B. (2005). İlköğretim Türkçe dersi öğretim programı ve kllavuzunun değerlendirilmesi. Kuram ve Uygulamada Eğitim Bilimleri, 5 (2), 477-516.

Balcı, A., Coşkun, E., \& Tamer, M. (2012). Cumhuriyet dönemi Türkçe dersi öğretim programlarının genel amaçları bakımından değerlendirilmesi. Dil ve Edebiyat Ĕ̆itimi Dergisi, 1(1), s .1-13.

Birinci, D.K. (2014). Merkezi sistem ortak sınavlarında ilk deneyim: Matematik dersi. Eğitim ve Öğretim Araştırmaları Dergisi, 3(2), 8-16.

Bowen, G. A. (2009). Document analysis as a qualitative research method. Qualitative research journal, 9(2), 27-40.

Çakmak, M , Gürbüz, H . (2012). Biyoloji eğitimi bölümü öğrencilerinin çevreye yönelik tutumlarının incelenmesi . Dicle Üniversitesi Ziya Gökalp Eğitim Fakültesi Dergisi , (19) , 162-173 . Retrieved from https://dergipark.org.tr/tr/pub/zgefd/issue/47945/606603

Demirel, Ö. (2012). Eğitimde program geliştirme. Ankara:Pegem.

\begin{tabular}{r|l} 
Adres & Address \\
RumeliDE Dil ve Edebiyat Araşttrmaları Dergisi & RumeliDE Journal of Language and Literature Studies \\
Osmanağa Mahallesi, Mürver Çiçeği Sokak, No:14/8 & Osmanağa Mahallesi, Mürver Çiçeği Sokak, No:14/8 \\
Kadıköy - İSTANBUL / TÜRKIYE 34714 & Kadıköy - ISTANBUL / TURKEY 34714 \\
e-posta: editor@rumelide.com & e-mail: editor@rumelide.com, \\
tel: +90 505 7958124, +90 2167730616 & phone: +90 505 7958124, +90 2167730616
\end{tabular}


Durukan, E. (2013). Öğretmen görüşleri açısından Türkçe dersi öğretim programı kazanımları. Karadeniz Sosyal Bilimler Dergisi, 5, 1-15.

Filiz, S. B. ve Yıldırım, N. (2019). Ortaokul Türkçe dersi öğretim programı kazanımlarının revize edilmiş bloom taksonomisine göre analizi. Elementary Education Online, 18(4).

Güzel, A. ve Karadağ, Ö. (2013). Anlatma becerileri açısından "Türkçe Dersi Öğretim Programı (6, 7, 8. Sinıflar)"na eleştirel bir bakış. Ana Dili Ĕ̆itimi Dergisi, 1(1), 45-52.

Nuhoğlu, M. M.; Başoğlu ve N.; Kayganacioğlu, S. (2008). Türkçe öğretiminde ölçme ve değerlendirme. Ankara: Nobel.

Özdemir, M. (2010). Nitel veri analizi: sosyal bilimlerde yöntembilim sorunsalı üzerine bir çalışma. Eskişehir Osmangazi Üniversitesi Sosyal Bilimler Dergisi, 11 (1), 323- 343.

Özden, M., Akgün, A., Çinici, A., Sezer, B., Yıldız, S., Taş, M.M. (2014). Merkezi sistem ortak sinav fen bilimleri sorularının webb’in bilgi derinliği seviyelerine göre analizi. Adıyaman Üniversitesi Fen Bilimleri Dergisi, 4(2), 91-108.

Özerbaş, M. A. (2007). Yapılandırmacı öğrenme ortamının öğrencilerin akademik başarılarına ve kalıcılı̆̆ına etkisi. Türk Ĕ̆itim Bilimleri Dergisi, 5(4), 609-635.

Şengül, S. ve Iş̧ı, S.C. (2014). 8. Sınıf öğrencilerinin üst bilişsel becerilerinin "Webb”in bilgi derinliği seviyeleri” ne ait problemleri çözme süreçlerindeki rolü. The Journal of Academic Social Science Studies,24, 93-127.

Üregen, R. N., Oral, K. H., Özkirişçi, N. A. ve Ünal, H. (2011). 2007-2008 oks matematik sorularının webb’in taksonomisine göre karşlaştırmalı analizi. III. Uluslararası Türkiye Eğitim Araştırmaları Kongre Kitabl, ss. 382-391. KKTC.

Varış, F. (1976). Eğitimde program geliştirme teori ve teknikler. Ankara: Ankara Üniversitesi Eğitim Fakültesi.

Webb, N. L. (2002, March). Depth of knowledge levels for four content areas. Unpublished manuscript. Wisconsin Center for Education Research, University of Wisconsin-Madison, Madison, WI.

Yıldırım, A. \& Şimşek, H. (2008). Sosyal bilimlerde nitel araştırma yöntemleri. Ankara: Seçkin.

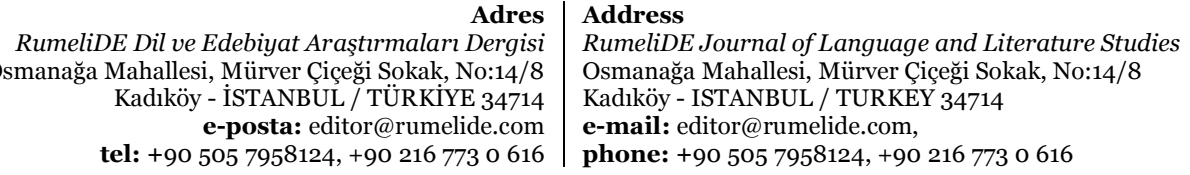

